\title{
СД-32. \\ СОРБЦИОННОЕ КОНЦЕНТРИРОВАНИЕ ГЛУТАМИНОВОЙ КИСЛОТЫ С ИСПОЛЬЗОВАНИЕМ ПРОДУКТОВ ТЕРМИЧЕСКОГО РАЗЛОЖЕНИЯ СЛОИСТЫХ ДВОЙНЫХ ГИДРОКСИДОВ
}

Севастьянова Е.В., Петрова Ю.Ю., Булатова Е.В.

БУ ВО Сургутский государственный университет, Сургут, Россия

yyp.71@mail.ru

DOI: 10.26902/ASFE-11_125

Слоистые двойные гидроксиды (СДГ) относят к классу двумерных анионных глин, имеющих слоистую структуру типа брусита. Научный интерес к ним связан с сорбционными свойствами и легкостью их модифицирования [1], что позволяет использовать их в качестве полифункциональных материалов. Например, перспективно сочетание сорбционных и магнитных свойств материалов. В данной работе были синтезированы магнитные материалы из $\mathrm{Mg}, \mathrm{Fe}(\mathrm{III})-$ и $\mathrm{Mg}$, Al-СДГ и изучены их сорбционные свойства. Синтез Mg,Fe(III)-СДГ проводили методом соосаждения, а затем их прокаливали при температурах 400,500 и $600^{\circ} \mathrm{C}$ в течение 4 ч. Синтез интеркалированных Mg,Fe(III),Al- и Mg,Al-СДГ проводили методом соосаждения с последующим прокаливанием и регидратацией комплексного аниона оксалата железа(III), затем прокаливали полученные СДГ при $400^{\circ} \mathrm{C}$ в течение 4 ч.

СДГ и продукты их термического разложения характеризовали методами ИКспектроскопии, лазерной дифракции, рентгенофазового и термического анализа. На ИКспектрах прокаленных СДГ отсутствовали полосы валентных колебаний ОН-групп, валентных и деформационных колебаний O-C=O-групп. Уменьшение среднего диаметра частиц после прокаливания можно объяснить разрушением слоистой структуры и изменением плотности электрического заряда на поверхности частиц. Методом рентгенофазового анализа было показано полное разрушение слоистой структуры прокаленных при 500 и $600^{\circ} \mathrm{C} \mathrm{Mg}$, $\mathrm{Fe}(\mathrm{III})-С Д Г$ и образование смешанных оксидов со структурой магнетита, шпинели и периклаза. Продукты термического разложения интеркалированных $\mathrm{Mg}$, Al- и Mg, Fe(III),AlСДГ представляли собой слоистые двойные оксиды, содержащие магнитные частицы $\mathrm{Fe}_{3} \mathrm{O}_{4}$ (магнетит). Методом дифференциального термического анализа наблюдали эндотермические эффекты при $200^{\circ} \mathrm{C}$ (удаление межслоевой воды и дегидратация металл-гидроксидных слоёв) и $400^{\circ} \mathrm{C}$ (разложение бруситоподобного слоя и оксалатного комплекса, а также потеря межслоевых карбонат-ионов).

Сорбционный эксперимент с использованием полученных продуктов термического разложения СДГ проводили в статических условиях из 10 мг/л глутаминовой кислоты при комнатной температуре. Максимальная равновесная сорбционная емкость 6.6 мг/г (степень извлечения 76\%) была получена для прокаленного при температуре $400^{\circ} \mathrm{C} \mathrm{Mg}, \mathrm{Fe}(\mathrm{III})-\mathrm{CДГ} \mathrm{с}$ соотношением $\mathrm{Mg}^{2+} / \mathrm{Fe}^{3+}$ 4:1, что можно объяснить частичным сохранением и восстановлением в растворе сорбата слоистой структуры. Кинетика сорбции глутаминовой кислоты на продуктах термической обработки интеркалированных $\mathrm{Mg}$, Al- и $\mathrm{Mg}, \mathrm{Fe}(\mathrm{III}), \mathrm{Al}-$ СДГ подчиняется модели псевдо-второго порядка, в то время как на прокаленных при $400^{\circ} \mathrm{C}$ $\mathrm{Mg}, \mathrm{Fe}(\mathrm{III})-\mathrm{CДГ} \mathrm{имеет} \mathrm{смешанный} \mathrm{характер,} \mathrm{т.е.} \mathrm{подчиняется} \mathrm{моделям} \mathrm{псевдо-первого} \mathrm{и}$ псевдо-второго порядков. Магнитные свойства прокаленных при $400^{\circ} \mathrm{C}$ интеркалированных $\mathrm{Mg}, \mathrm{Al}-$ и $\mathrm{Mg}, \mathrm{Fe}(\mathrm{III}), \mathrm{Al}-\mathrm{CДГ} \mathrm{и} \mathrm{при} \mathrm{500-600} \mathrm{C} \mathrm{Mg,Fe(III)-СДГ} \mathrm{после} \mathrm{сорбции} \mathrm{сохраняются,} \mathrm{что}$ позволяет легко отделять их из растворов в магнитном поле.

\section{Список литературы}

1. Jiao, F., Shuai, L., Yu, J., Jiang, X., Chen, X., and Du, S., Trans. Nonferrous Met. Soc. China, 2014, vol. 24 , p. 3971. 